\title{
INFLUENCE OF CLIMATE CHANGE ON SOIL WATER REGIME IN KOPRIVNICA-KRIŽEVCI COUNTY
}

\author{
ANDRIJA SPOLJAR ${ }^{1}$, IVICA KISIC ${ }^{2 *}$, TOMISLAVA PEREMIN VOLF ${ }^{1}$, DRAGUTIN \\ KAMENJAK ${ }^{1}$, DRAZEN KAUCIC ${ }^{3}$
}

${ }^{1}$ College of Agriculture at Krizevci, Milislava Demerca 1, 48260 Krizevci, Croatia; e-mail: aspoljar@vguk.hr, tperemin@vguk.hr

${ }^{2}$ Faculty of Agriculture University of Zagreb, Svetosimunska cesta 25, 10000 Zagreb, Croatia; e-mail: ikisic@agr.hr

${ }^{3}$ Meteorological and Hydrological Service, Gric 3, 10000 Zagreb, Croatia; e-mail: kaucic@cirus.dhz.hr

* Author for correspondence

\begin{abstract}
Spoljar A., Kisic I., Peremin Volf, T., Kamenjak D., Kaucic D.: Influence of climate change on soil water regime in Koprivnica-Krizevci County. Ekológia (Bratislava), Vol. 33, No. 2, p. 178-187, 2014.

The influence of climate change on soil water regime was investigated in the area of Koprivnica-Krizevci County (Republic of Croatia). Water balance calculations were done for three climatic stations using Thornthwaite and Palmer water balance methods. In the 18-year period (from 1991 to 2008), compared with the previously observed 30-year period (from 1961 to 1990), the increase in average mean annual temperature was $1^{\circ} \mathrm{C}$. Regarding the global warming, there was an increase in plant water potential during the investigated period. Compared with the previous period and according to Thornthwaite and Palmer methods, there was an increase in water deficit. Negative linear trend in precipitation was detected for all climate stations in the investigated area $(p>0.05)$ as well as positive linear trend in mean annual temperature $(p<0.05)$. The calculation of linear trend in water deficit in soil, according to Thornthwaite method, shows that by the year 2020 there could be an increase in water deficit by an average of $13 \mathrm{~mm}(p>0.05)$, whereas according to the Palmer method there could be an increase by an average of $9 \mathrm{~mm}(p<0.05$ only for the climate station in Krizevci).
\end{abstract}

Key words: climate change, droughts, soil water regime, water balance.

\section{Introduction}

Since droughts with unwanted consequences for the agricultural production have lately become more frequent, numerous investigations have been conducted regarding the influence of global warming on the soil water regime changes, both in Croatia and in the world. Using computer methods, adverse changes in soil water regime caused by frequent droughts in different parts of the world have been confirmed by numerous authors (Daly et al., 2006; Hernadi et al., 2009; Jiang et al., 2007; Porporato et al., 2004; Tao et al., 2005; Yang et al., 2008). On the basis of water balance computations according to the Thornthwaite method, Mesic et al., (2001) estimate that there will be an increase in water deficit by 30 to $60 \%$ in 
lowland Croatia during the months of summer, as well as an increase in the annual number of days with temperature higher than $10^{\circ} \mathrm{C}$, by 25 to 40 days. Racz et al., (1998) estimate, due to global warming, a significant increase of evapotranspiration in the whole area of south Europe that will reduce, as stated, average moisture reserves in soil by 15 to $25 \%$. Similar estimates, with the increasing threat of drought in some areas of Croatia, are given by Bonacci (1993) and Pandzic (1993). In the next 50 years, according to climate models, a global surface temperature increase of $3{ }^{\circ} \mathrm{C}$ can be expected, and the consequences could be significant (Pandzic, 1998). The results of Spoljar et al., (2004) in the area of Krizevci are in favour of this statement. The authors determined significantly greater water deficit in the past 16 years in comparison to two previously investigated 30-year periods.

It is assumed that, with respect to drought, in the entire area of Koprivnica-Krizevci County adverse changes have occurred in soil water regime, with possible adverse consequences on agricultural production. Thus, the objectives of this investigation included the comparison of the following:

- Climatic conditions during the past 18 years and the 30 -year period for climate stations in Djurdjevac, Koprivnica and Krizevci,

- The components of water balance for these two periods, according to Thornthwaite and Palmer methods.

Based on such objectives of investigation, it is possible to assess the effect of climate change (drought) on soil water regime.

\section{Material and methods}

Corrected potential evapotranspiration $\left(\mathrm{PET}_{\mathrm{k}}\right)$ was calculated using the Thornthwaite method, and the soil water balance was calculated using Thornthwaite and Palmer methods. Monthly precipitation and mean monthly temperature data, provided by the Meteorological and Hydrological Service of Croatia, were used to calculate corrected potential evapotranspiration $\left(\mathrm{PET}_{\mathrm{k}}\right.$ ) by the Thornthwaite method. Data of the Basic Soil Map of the Republic of Croatia at the scale of 1:50 000 and the corresponding legends, as well as representative soil profile data for Albic Luvisol (FAO, 1998), a predominant soil type in the County, were used to calculate water balance by the Palmer method. Water run-off (RO) and deficit of soil moisture storage to the depth of $0.5 \mathrm{~m}$ were calculated using a computer programme Hydropedokalk (Siric, Vidacek, 1997). Mean available water capacity for five soil profiles was $196.5 \mathrm{~mm}$ at a depth of $10-50 \mathrm{~cm}$, mean value of soil moisture capacity was $39.8 \mathrm{~mm}$ at a depth of $10 \mathrm{~cm}\left(\mathrm{z}_{1}\right)$ and $149.0 \mathrm{~mm}$ at a depth of $10-50 \mathrm{~cm}\left(\mathrm{z}_{2}\right)$.

Climatic characterisation was done according to Lang's rain factor calculation. Data on annual precipitation and mean annual temperature, values of corrected potential and actual evapotranspiration according to the Thornthwaite method, actual evapotranspiration according to the Palmer method, as well as data on soil water deficit and surplus were statistically processed and a linear trend was calculated $(p<0.05)$.

\section{Results}

\section{Climatic characteristics of Koprivnica-Krizevci County}

Mean monthly and annual temperature data, as well as monthly and annual precipitation for the 30-year period, from 1961 to 1990, and for the period from 1991 to 2008 in KoprivnicaKrizevci County for climate stations in Djurdjevac, Koprivnica and Krizevci, are shown in Fig. 1. 


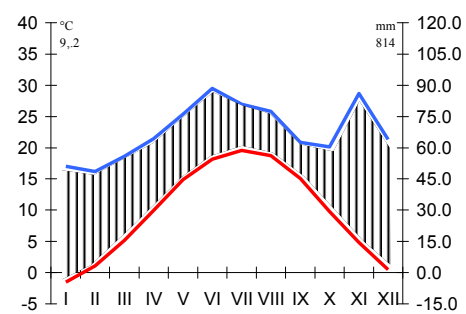

एس] wet spell

rainfall distribution temperature distribution
Koprivnica 1961 - 1990

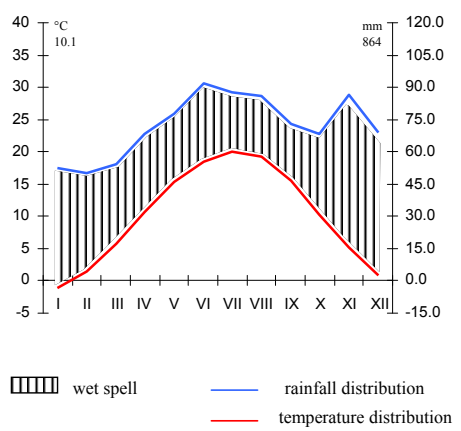

Koprivnica 1961 - 1990

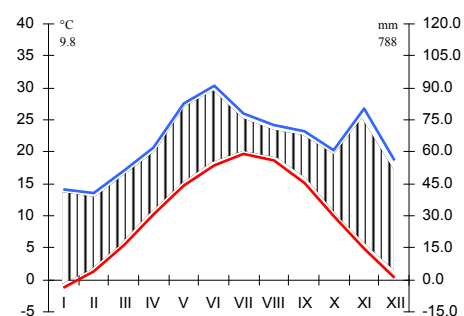

एس] wet spell

rainfall distribution temperature distribution

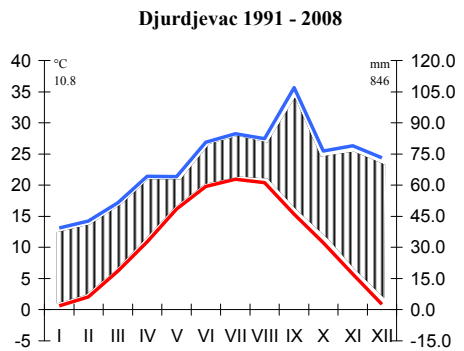

एس] wet spell

rainfall distribution

temperature distribution
Koprivnica 1991 - 2008

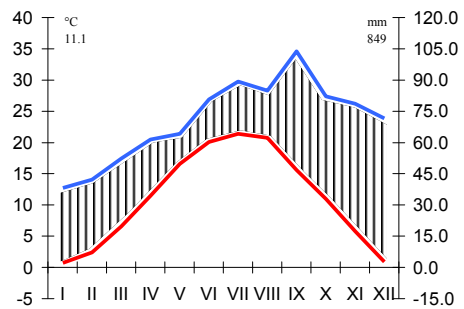

एس] wet spell rainfall distribution temperature distribution

Fig. 1. Climate diagram according to Walter. 
Compared with the previously observed 30-year period, during the 18 -year period the increase in average mean annual temperature was $1{ }^{\circ} \mathrm{C}$, whereas the increase in annual precipitation was $5 \mathrm{~mm}$. The highest mean monthly temperatures in both investigated periods were observed in July, and the lowest in January. The minimum precipitation in the 30 -year period was recorded during winter, and at the beginning of spring, and maximum in June. In contrast, in the last 18 years, maximum precipitation was recorded in September, and minimum precipitation in winter and at the beginning of spring.

Based on the average value of Lang rain factor (RF) during the past 18 years, the climate in the County has been semihumid $(\mathrm{RF}=76.1)$, while in the previous period it had been humid $(R F=83.3)$. Based on the above, it can be said that a certain amount of warming has occurred, and that it influenced the soil water regime. Frequent droughts have been recorded, and consequently, the deficit in soil moisture storage has occurred. This statement is confirmed by water balance analysis performed according to Thornthwaite and Palmer methods.

\section{Soil water balance}

The results for the water balance components according to Thornthwaite and Palmer methods for the investigated periods from 1961 to 1990 and from 1991 to 2008 are shown in Table 1. The value of corrected potential evapotranspiration $\left(\mathrm{PET}_{\mathrm{k}}\right)$, representing plant water potential in the past 18 years, compared with the previously investigated period, was higher by an average of $35 \mathrm{~mm}$. Actual evapotranspiration (AET) was determined by the Thornthwaite method and compared with previously investigated period the value was lower by an average of $10 \mathrm{~mm}$, while actual evapotranspiration (AE) by the Palmer method was higher by $19 \mathrm{~mm}$.

T a b le 1. Soil water balance according to Thornthwaite and Palmer methods.

\begin{tabular}{|c|c|c|c|c|c|c|c|}
\hline \multirow[t]{3}{*}{ Method } & \multirow{3}{*}{$\begin{array}{l}\text { Data, } \\
\mathrm{mm}\end{array}$} & \multicolumn{6}{|c|}{ Period } \\
\hline & & \multicolumn{3}{|c|}{$1961-1990$} & \multicolumn{3}{|c|}{$1991-2008$} \\
\hline & & Djurdjevac & Koprivnica & Krizevci & Djurdjevac & Koprivnica & Krizevci \\
\hline \multirow[t]{4}{*}{ Thornthwaite } & $\mathrm{PET}_{\mathrm{k}}$ & 649.9 & 664.4 & 650.8 & 688.0 & 699.7 & 683.3 \\
\hline & AET & 617.9 & 655.7 & 629.9 & 626.0 & 637.1 & 609.0 \\
\hline & SWD & 31.9 & 8.7 & 20.9 & 62.0 & 62.6 & 74.4 \\
\hline & SWS & 198.1 & 211.0 & 157.9 & 219.6 & 212.2 & 177.9 \\
\hline \multirow[t]{3}{*}{ Palmer } & $\mathrm{AE}$ & 616.9 & 643.2 & 624.3 & 639.3 & 652.0 & 649.3 \\
\hline & ET-AE & 31.7 & 21.3 & 26.5 & 47.2 & 47.6 & 57.6 \\
\hline & $\mathrm{RO}$ & 199.2 & 223.5 & 163.3 & 206 & 197.2 & 1376 \\
\hline \multicolumn{2}{|c|}{$\mathrm{RF}$} & \multicolumn{3}{|c|}{83.3} & \multicolumn{3}{|c|}{76.1} \\
\hline
\end{tabular}

Notes: PETk - corrected potential evapotranspiration, AET - actual evapotranspiration according to Thornthwaite, SWD - soil water deficit according to Thornthwaite, SWS - soil water surplus according to Thornthwaite, AE actual evapotranspiration according to Palmer, ET-AE - water deficit according to Palmer, RO - run-off according to Palmer, RF - Lang's rain factor.

Plant water potential, as the results have shown, has grown during the investigated years. However, sufficient water supply was not available to plants. Water deficit obtained by both methods was higher in comparison with the previous period. According to the Thornthwaite 
method, the water deficit in comparison with the previously investigated period was higher by an average of $46 \mathrm{~mm}$, and according to the Palmer method by $24 \mathrm{~mm}$. The obtained water surplus value according to the Thornthwaite method was higher by an average of $14 \mathrm{~mm}$ for the last period, and according to the Palmer method it was lower by $15 \mathrm{~mm}$.

The results of statistical analysis of water balance components according to Thornthwaite and Palmer methods were processed and a linear trend was calculated $(p<0.05)$. A linear trend in precipitation for the climate stations in Djurdjevac, Koprivnica and Krizevci is shown in Fig. 2.
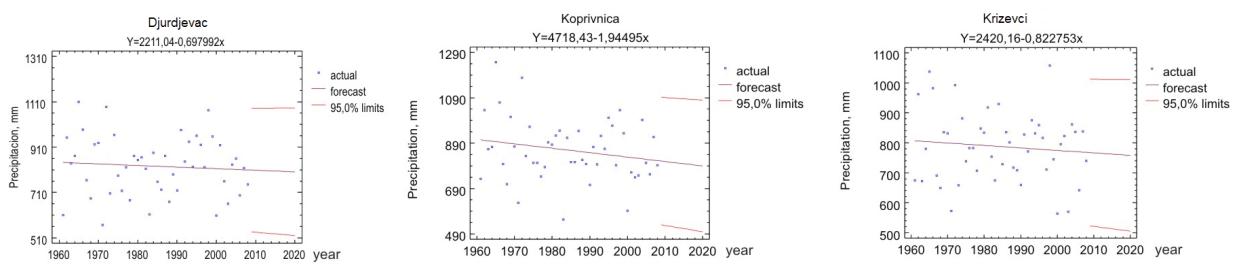

Fig. 2. Linear trend in precipitation.

Negative linear trend in precipitation was detected for all climate stations in the investigated area $(p>0.05)$. Assuming that precipitation will follow a linear decrease, in the coming decade there could be a decrease in precipitation by an average of $13 \mathrm{~mm}$ in the area of the County.

Positive linear trend in mean annual temperature was detected $(p<0.05)$ (Fig. 3). Based on a linear trend calculation, it can be assumed that by 2020 mean annual temperature will grow by an average of $0.4{ }^{\circ} \mathrm{C}$. The increase in mean annual temperature, with concurrent decrease of the amount of rainfall, had affected and caused an increase in the demand for water within plants.
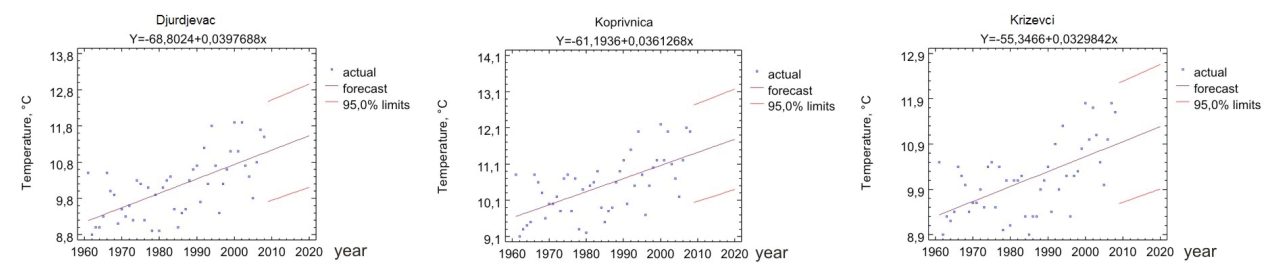

Fig. 3. Linear trend in mean annual temperature.

Assuming that this trend will continue, there will be an increase in the values of corrected potential evapotranspiration $\left(\mathrm{PET}_{\mathrm{k}}\right)$ in the coming decade by an average of $13 \mathrm{~mm}(p<0.05)$ (Fig. 4). A negative trend in the values of actual evapotranspiration (AET) according to the Thornthwaite method was detected for climate stations in Krizevci and Koprivnica, as well as a positive trend for the climate station in Djurdjevac $(p>0.05)$ (Fig. 5). A positive linear trend of actual evapotranspiration (AE) according to the Palmer method ( $p>0.05)$ was detected, and is shown in Fig. 6. 

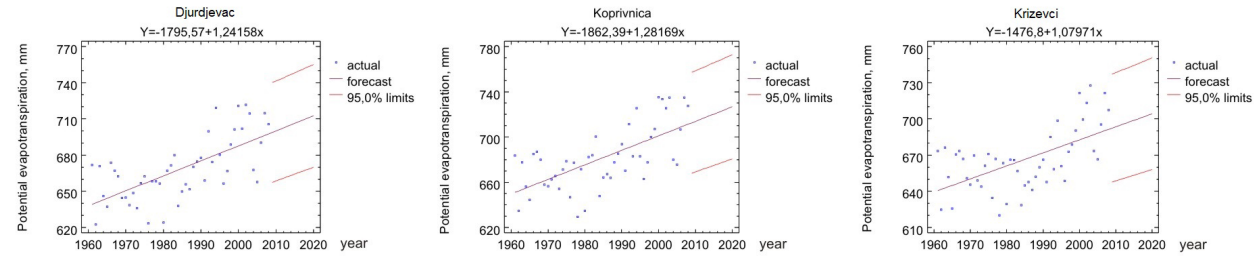

Fig. 4. Linear trend in corrected potential evapotranspiration $\left(\mathrm{PET}_{\mathrm{k}}\right)$.
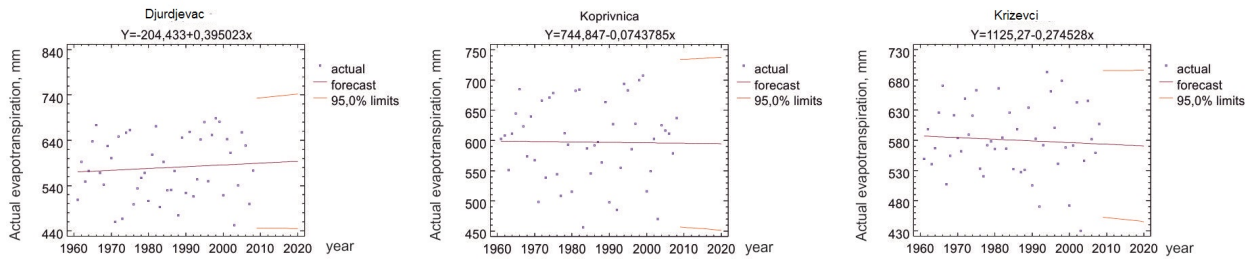

Fig. 5. Linear trend in actual evapotranspiration according to Thronthwaite (AET).
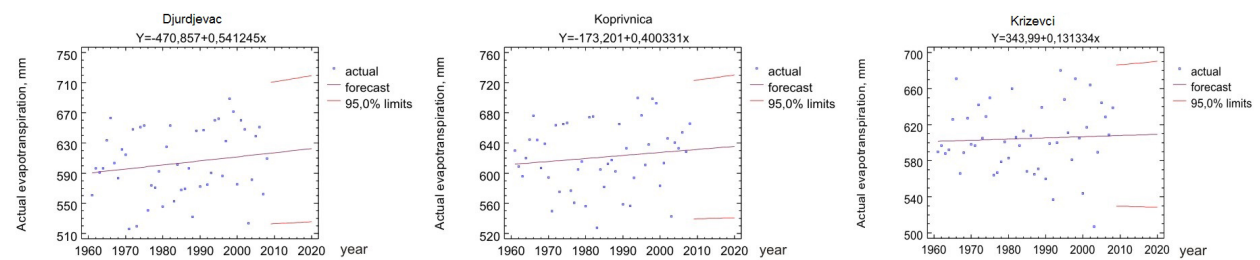

Fig. 6. Linear trend in actual evapotranspiration according to Palmer (AE).
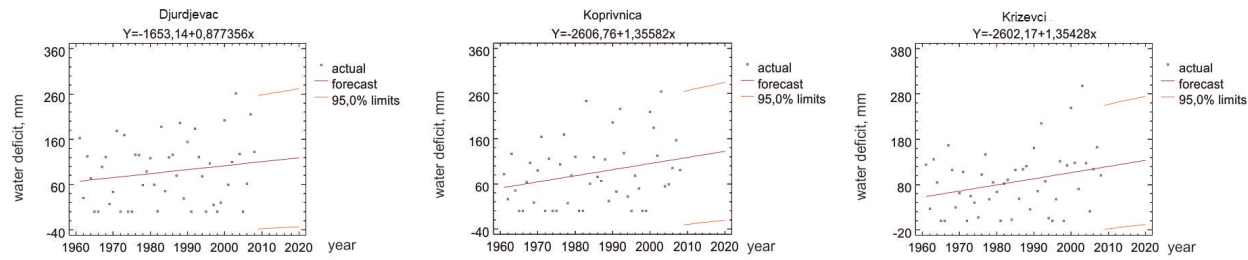

Fig. 7. Linear trend in water deficit according to Thornthwaite method.

Lack of rainfall, increase in mean temperature and corrected potential evapotranspiration $\left(\mathrm{PET}_{\mathrm{k}}\right)$ had a negative influence on soil water balance. The calculation of a linear trend in soil water deficit according to the Thornthwaite method shows that by 2020 there could be an increase in water deficit by an average of $13 \mathrm{~mm}(p>0.05)$ (Fig. 7), and according to the Palmer method by an average of $9 \mathrm{~mm}$ (Fig. 8). The value of linear trend in water deficit is statistically significant only for the climate station in Krizevci $(p<0.05)$. According to the Thornthwaite method, there could be a decrease in water surplus by an average of $13 \mathrm{~mm}(p>$ 0.05 ) in the following decade, as shown in Fig. 9. Similar results were obtained using Palmer 
method, and there could be a decrease in water surplus by $18 \mathrm{~mm}$, in the same period, as shown in Fig. 10. However, statistically significant values were obtained only for the climate station in Koprivnica $(p<0.05)$.
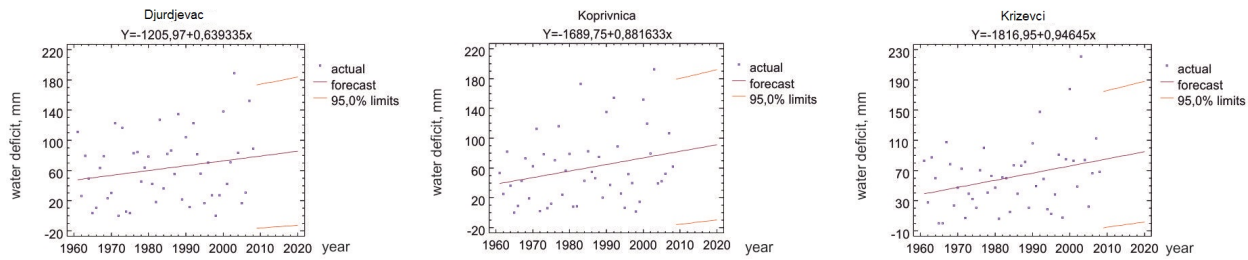

Fig. 8. Linear trend in water deficit according to Palmer method.
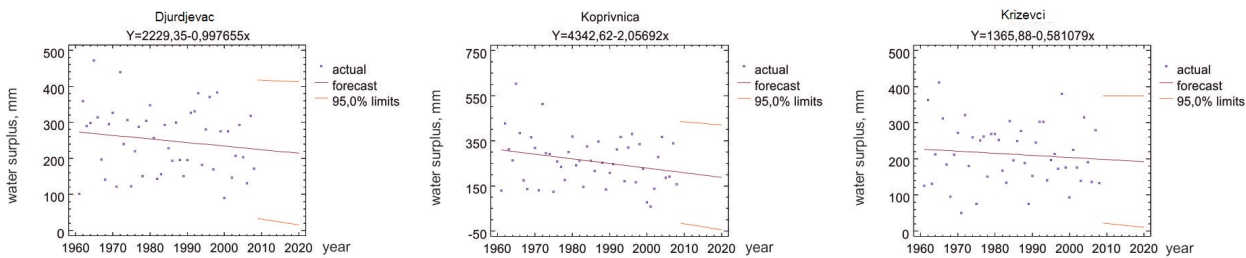

Fig. 9. Linear trend in water surplus according to Thornthwaite method .
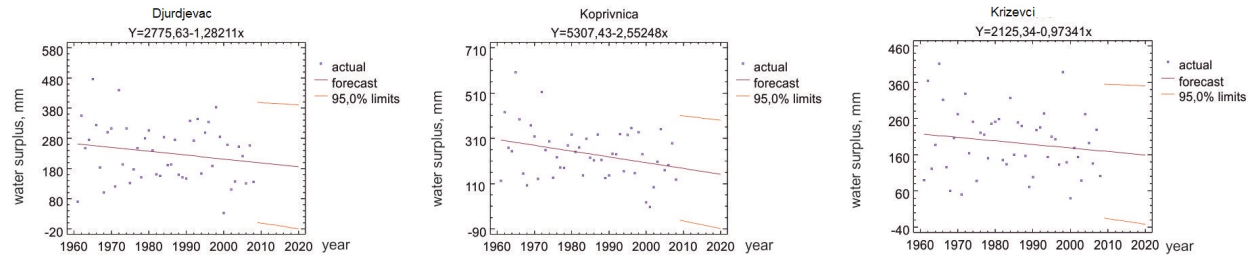

Fig. 10. Linear trend in water surplus according to Palmer method.

\section{Discussion}

The results show that in the area of Koprivnica-Krizevci County, a certain warming has occurred, which has negative consequences on the soil water regime. Plant water potentials have grown, and plant water availability has not been sufficient. The observed water deficit during the past 18 years was higher in comparison to the previously investigated 30 -year period.

Similar results were obtained by Elgaali et al. (2006), who investigated possible influence of climate change on plant water potential and soil water storage capacity by using mathematical methods. Using computer methods, the adverse changes in soil water regime caused by frequent droughts and inadequate soil management were also observed by Sato et al. (2008). Škvarenina et al. (2004) estimate that climate change will have adverse influence on the value of potential evapotranspiration and, as the authors report, significant wa- 
ter deficit for most plant species will occur. Also, Yang et al. (2008) established a significant water deficit for growing of most agricultural crops, due to global warming. The adverse changes in soil water regime caused by drought were observed by other authors (Islam et al., 2005; Jiang et al., 2007; Moroizumi et al., 2009; Yang et al., 2008).

Frequent droughts, and consequently a decrease in soil moisture storage, adversely affect the yield of crops grown (Spoljar et al., 2004) and in the near future, the consequences could be even greater. Therefore, it is considered necessary to provide new water resources in the County, and, of course, respond to greater irrigation demand, especially regarding commercial crops such as fruits and vegetables. Sun et al. (2006) determined higher values of evapotranspiration in winter wheat growing and therefore a greater irrigation demand due to global warming. Investigating the influence of water stress on winter wheat yield, using computer methods, Eitzinger et al. (2007) estimated a considerable reduction in grain yield. Regarding frequent droughts and adverse hydrological changes in general, in order to provide a stable agricultural production, numerous authors recommend the provision of new water resources and an adequate response to irrigation demands (Elgaali et al., 2006; Jiang et al., 2007; Moroizumi, 2009).

Moreover, in agricultural production more attention should be paid to conservation tillage and the cultivation of crops in the rotation. Favourable impact of conservation tillage compared with other tillage methods that were investigated, with respect to increasing moisture content in soil, was obtained by numerous authors (Fabrizzi et al., 2005; Jin et al., 2007; Lenssen et al., 2007; Sessiz et al., 2008). Spoljar et al. (2011) suggested that growing crops in rotation, by combined application of organic and mineral fertilization with liming, can reduce adverse influence of drought and can result in higher and more stable yields of crops.

\section{Conclusion}

Based on the above observations, the following conclusions can be made:

During the 18-year period (from 1991 to 2008), compared with previously investigated 30-year period (from 1961 to 1990), mean annual temperature was higher by an average of $1{ }^{\circ} \mathrm{C}$, and annual precipitation was higher by $5 \mathrm{~mm}$. Regarding global warming, plant water potential during the investigated years has grown; however, water availability to plants has not been sufficient. Water deficit, according to both water balance methods, was higher in comparison to the previous period.

A negative linear trend in precipitation $(p>0.05)$ as well as a positive linear trend in mean annual temperature $(p<0.05)$ was detected for all climate stations in the investigated area. The calculation of linear trend in water deficit using the Thornthwaite method shows that by the year 2020 there could be an increase in water deficit by $13 \mathrm{~mm}(p>0.05)$, and using the Palmer method the average increase is $9 \mathrm{~mm}(p<0.05$ only for the climate station in Križevci). Water surplus calculated using the Thornthwaite method could mark a decrease by an average of $13 \mathrm{~mm}(p>0.05)$ in the following 10 -year period. Similar results were obtained using Palmer method, and water surplus could mark a decrease by $18 \mathrm{~mm}$ in 
the same period. However, statistically significant values were obtained only for the climate station in Koprivnica $(p<0.05)$.

Frequent droughts, and consequently a greater soil moisture deficit, adversely affect the yield of crops grown, and in the near future the consequences could be even greater. Therefore, it is considered necessary to provide new water resources in the County, implement soil management methods which have beneficial effect on moisture conservation and, of course, respond to a greater irrigation demand, especially regarding commercial crops such as fruits and vegetables.

\section{References}

Bonacci, O. (1993). Draught identification and prevention. In Proceedings of Roundtable on drought (pp. 1-20). Zagreb: Croatian Hydrological Society and Croatian Society for Irrigation and Drainage.

Daly, E. \& Porporato A. (2006). Impact of hydroclimatic fluctuations on the soil water balance. Water Resources Research, 42(6), 6401. DOI: 10.1029/2005WR004606.

Eitzinger, J., Štastná, M., Žalud, Z. \& Dubrovský M. (2003). A simulation study of the effect of soil water balance and water stress on winter wheat production under different climate change scenarios. Agric. Water Manag., 61(3), 195-217. DOI: 10.1016/S0378-3774(03)00024-6.

Elgaali, E., Garcia, L.A. \& Ojima D.S. (2006). Sensitivity of irrigation water balance to climate change in the Great plains of Colorado. Transactions of the ASABE, 49(5), 1315-1322. DOI: 10.13031/2013.22048.

Fabrizzi, K.P., Garcia, F.O., Costa, J.L. \& Picone L.I. (2005). Soil water dinamics, physical properties and corn and wheat responses to mimimum and no-tillage ystems in the southern pampas of Argentina. Soil Tillage Res., 81, 57-69. DOI: 10.1016/j.still.2004.05.001.

FAO (1998). FAO-Unesco Soil mMap of the World. World Soil resources, Report 60. Rome: FAO/Unesco/ISRIC.

Hernádi, H., Farkas, C., András, M. \& Ferenc M. (2009). Climate sensitivity of soil water regime of different Hungarian Chernozem soil subtypes. Biologia, 64(3), 496-501. DOI: 10.2478/s11756-009-0085-8.

Islam, M., Aramaki, T. \& Hanaki K. (2005). Development and application of an integrated water balance model to study the sensitivity of Tokyo metropolitan area water availability scenario to climate changes. Water Resources Management, 19(4), 423-445. DOI: 10.1007/s11269-005-3277-1.

Jiang, T., Chen, Y.D., Xu, C.Y., Chen, X. \& Singh V.P. (2007). Comparison of hydrological impacts of climate changes simulated by six hydrological models in the Dongjiang Basin, South China. J. Hydrol., 336(3-4), 316-333. DOI: 10.1016/j.jhydrol.2007.01.010.

Jin, K., Cornelis, W.M., Schicttecatte, W., Lu, J.J., Yao, Y.O., Wu, H.J., Gabriels, D., De Neve, S., Cai, D.X., Jin, J.Y. \& Hartman R. (2007). Effects of management practices on soil-water balance and crop yield for improved dryland farming in the Chinese loess Plateau. Soil Tillage Res., 96(1-2), 131-144. DOI: 10.1016/j. still.2007.05.002.

Lenssen, A.W., Johnson, G.D. \& Carlson G.R. (2007). Cropping sequence and tillage system influences annual crop production and water use in semiarid Montana. Field Crops Res., 100, 32-43. DOI: 10.1016/j. fcr.2006.05.004.

Mesic, M., Basic, F. \& Kisic I. (2001). The adjusting of agricultural systems to possible climate change. In Scientific conference of Croatian agriculturists with international participation (p. 54). Opatija: Croatian Society of Agronomists.

Moroizumi, T., Hamada, H., Sukchan, S. \& Ikemoto M. (2009). Soil water content and water balance in rainfed water fields in Northeast Thailand. Agric. Water Manag., 96(1), 160-166. DOI: 10.1016/j.agwat.2008.07.007.

Pandzic, K. (1993). Climate and meteorological aspects of drought. In Proceedings of Roundtable on drought (pp. 21-27). Zagreb: Croatian Hydrological Society and Croatian Society for Irrigation and Drainage.

Pandzic, K. (1998). Global climate change scenario and interpretation. In Proceedings of Roundtable Water on the Croatian Islands (pp. 233-241). Hvar: Croatian Hydrological Society.

Porporato, A., Daly, E. \& Rodriguez-Iturbe I. (2004). Soil water balance and ecosystem response to climate change. Am. Nat., 164(5), 625-632. DOI: 10.1086/424970.

Racz, Z., Vidacek, Z., Kaucic, D. \& Mihalic A. (1998). Impact of precipitation on water regime and soil moisture deficit. In Proceedings of Scientific conference with international participation on the adaptation of agriculture 
and forestry to climate and its changes (pp. 75-83). Zagreb: Croatian Academy of Sciences and Arts.

Sato, Y., Ma, X., Xu, J., Matsuoka, M., Zheng, H., Liu, C. \& Fukushima Y. (2008). Analysis of long-term water balance in the source area of the Yellow River basin. Hydrological Processes, 22(11), 1618-1629. DOI: 10.1002/ hyp. 6730 .

Sessiz, A., Sogut, T., Alp, A. \& Esgici R. (2008). Tillage effects on sunflower (Helianthuus annuus L.) emergence, yield, quality, and fuel consumption in double cropping system. Journal of Central European Agriculture, 9(4), 697-710.

Siric, I. \& Vidacek Z. (1997). Hydropedokalk - computer programme for calculation of soil water balance of precipitation. Zagreb: Department of Pedology, Faculty of Agriculture University of Zagreb.

Spoljar, A., Husnjak, S., Peremin Volf, T., Dadacek, N. \& Kvaternjak I. (2004). Irrigation requirements in the area of Križevci. Croatian Waters, 12(49), 319-326.

Spoljar, A., Kisic, I., Birkas, M., Gunjaca, J. \& Kvaternjak I. (2011). Influence of crop rotation, liming and green manuring on soil properties and yields. Journal of Enviromental Protection and Ecology, 12(1), 54-69.

Sun, H.Y., Lin, C.M., Zhang, X.Y., Shen, Y.J. \& Zhang Y.Q. (2006). Effects of irrigation on water balance, yield and WUE wheat in the North China Plain. Agric. Water Manag., 85(1-2), 211-218. DOI: 10.1016/j.agwat.2006.04.008.

Škvarenina, J., Križová, E. \& Tomlain J. (2004). Impact of the climate change on the water balance of altitudinal vegetation stages in Slovakia. Ekológia (Bratislava), 23(Suppl. 2), 13-29.

Tao, F.L., Yakozawa, M., Hayashi, Y. \& Lin E.D. (2005). A perspective on water resources in China: Interactions between climate change and soil degradation. Clim. Change, 68(1-2), 169-197. DOI: 10.1007/s10584-0056013-1.

Yang, Y., Feng Z., Huang, H.Q. \& Lin Y. (2008). Climate - induced changes in crop water balance during 19602001 in Northwest China. Agric. Ecosyst. Environ., 127(1-2), 107-118. DOI: 10.1016/j.agee.2008.03.007. 